\title{
Forage based animal production systems and sustainability, an invited keynote
}

\author{
Abdul Shakoor Chaudhry \\ School of Agriculture, Food and Rural Development, Newcastle University, United Kingdom, NE1 7RU
}

ABSTRACT - Forages are essential for the successful operation of animal production systems. This is more relevant to ruminants which are heavily dependant upon forages for their health and production in a cost-effective and sustainable manner. While forages are an economical source of nutrients for animal production, they also help conserve the soil integrity, water supply and air quality. Although the role of these forages for animal production could vary depending upon the regional preferences for the animal and forage species, climate and resources, their importance in the success of ruminant production is acknowledged. However with the increasing global human population and urbanisation, the sustainability of forage based animal production systems is sometimes questioned due to the interrelationship between animal production and the environment. It is therefore vital to examine the suitability of these systems for their place in the future to supply quality food which is safe for human consumption and available at a competitive price to the growing human population. Grassland and forage crops are recognised for their contribution to the environment, recreation and efficiency of meat and milk production,. To maintain sustainability, it is crucial that such farming systems remain profitable and environmentally friendly while producing nutritious foods of high economical value. Thus, it is pertinent to improve the nutritive value of grasses and other forage plants in order to enhance animal production to obtain quality food. It is also vital to develop new forages which are efficiently utilised and wasted less by involving efficient animals. A combination of forage legumes, fresh or conserved grasses, crop residues and other feeds could help develop an animal production system which is economically efficient, beneficial and viable. Also, it is crucial to use efficient animals, improved forage conservation methods, better manure handling, and minimum fertilisers to maximise animal production without damaging the environment. The sensible use of supplements and herbal additives as the desirable alternatives to the conventional growth promoters could also help optimise the ruminant production. This paper examines the opportunities and obstacles which may affect the development of more desirable and sustainable animal production systems for the future.

Keywords: Animal Production Systems; Forages; Ruminants; Sustainable

\section{Introduction}

Forage based animal production plays a crucial role in the affordable supply of nutrient rich foods for the humans. However, over the past 60 years, animal production has changed substantially due to the concerted efforts in modern technology, animal breeds, management, growth promoters, feed additives and financial incentives. The benefits of these efforts are more visible in the developed world where animal derived food production has soared involving fewer but bigger farms. Despite this global increase in animal derived foods, about 1 billion people are still regarded as either undernourished or living in poverty (FAO, 2000). While, the corporate farming is beneficial in terms of effective management and food security, it has created issues of animal welfare, environment, food safety and social aspects of family farming. As large scale farming involves high inputs, it can damage animal health, food safety, soil quality, subsoil water and wildlife. Moreover, intensive Livestock farming has affected the social aspects of small scale family farmers and other countryside inhabitants.

Due to the above mentioned issues, the sustainability of modern animal production systems is commonly questioned by the consumers, conservationists, environmentalists and the policy makers alike. Even the animal related industries have begun to realise that their current practices may not be sustainable and so they need to adopt appropriate measures to help sustain animal production to suit the dietary needs of the current and future generations of both developed and developing countries. Although, it can bring benefits for social, economical and environmental issues in different regions, the success of a sustainable animal production system depends upon a 
multi-disciplinary approach involving suitable animals, forages, grassland and other associated components. This paper examines the feasibility of such an approach in developing a desirable and sustainable animal production for the future.

\section{What is sustainable animal production?}

Sustainable Animal Production can be defined as the production that should meet the needs of the current generation without affecting the ability of future generations to meet their own needs (Oltjan \& Becket, 1996; UN, 1987; Vavra 1996). Here, the term 'needs' refers not only to the dietary needs, but also to the social, cultural, environmental and economical issues that the current or future generations of human beings face. However, the scope, opportunity and implication of such needs can vary depending upon the locations and economical status of these generations.

\section{Global Human Population and Animal Production}

It is expected that the global human population will reach 7.6 billion by 2020 and over $85 \%$ of this increase will take place in the developing world (FAO 2000). If this trend of population growth continues then by 2030 over 1.5 billion more people will be added to make the world human population around 8.3 billion (Table 1). While the population growth will reduce slightly in Asia, it will increase in Africa. Conversely, the growth rate in Europe and North America will stabilise during the same period. It is predicted that Asia and Africa together will represent over $75 \%$ of global human population in 2010 and over 79\% in 2050. This obviously will have an impact on the demand for more food supply for export from the developed to the developing parts of the world.

Table 1. Predicted Populations for World, Asia and Africa

\begin{tabular}{|c|c|c|c|c|c|}
\hline Regions & 2010 & 2020 & 2030 & 2040 & 2050 \\
\hline $\begin{array}{c}\text { World } \\
\text { (Billions) }\end{array}$ & 6.8 & 7.6 & 8.3 & 8.9 & 9.4 \\
\hline Asia (\%) & 60.7 & 60.6 & 60.1 & 59.4 & 59 \\
\hline Africa (\%) & 14.4 & 15.7 & 17.2 & 18.7 & 20.2 \\
\hline $\begin{array}{c}\text { Asia +Africa } \\
\text { (\%) }\end{array}$ & 75.1 & 76.3 & 77.3 & 78.1 & 79.2 \\
\hline
\end{tabular}

Figure 1 shows that despite the increasing trend in population growth in developing regions, the rural and agricultural populations will not change in these regions over the next 20 years.

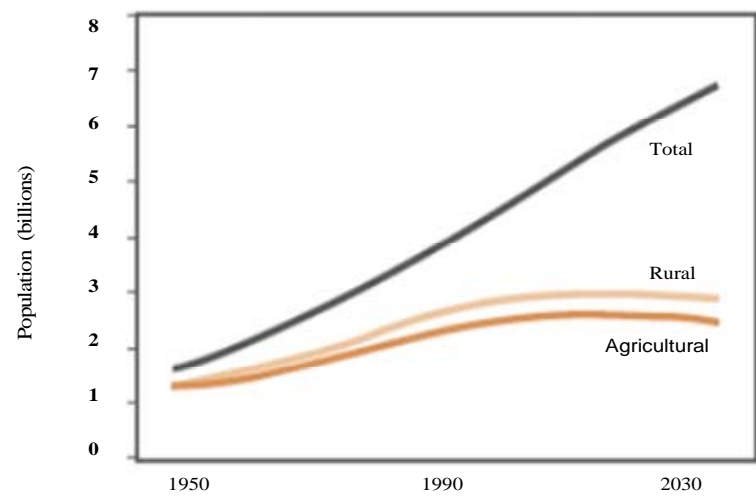

Figure 1. Population Trends in Developing Regions (Hall et al., 2001)

This implies that fewer workers may be available to participate in farming activities. Conversely, with the predicted increase in the total population and with the current estimate of 1 billion people who are either undernourished or impoverished, there will be more demand for animal derived foods in years to come (Hall et al., 2001).

\section{Ruminant Livestock and Sustainability}

Ruminant livestock are essential in the supply of high quality foods such as meat and milk for human populations. Their role in the sustainability of forage based animal production systems is important as they require less or no cereal grains which are an essential energy source for humans (Oltjan and Beckett, 1996). In fact these animals are blessed with the rumen which acts as a fermentation vat to convert indigestible fibrous materials into high quality food such as milk and meat. These fibrous materials are abundantly available as renewable resources from pastures, trees, forests, woodlands, crop residues and other agro-industrial byproducts. The conversion of these cellulose rich waste products by the naturally inhabiting rumen microbes into high quality food is a highly desirable feature which should be harnessed to utilise fibrous byproducts and achieve sustainable animal production. 
The ruminants also contribute to the fertility of soils through their faeces and urine and so transform some unproductive lands for their productive use to produce food or cash crops for the human population.

\section{Developing a Sustainable Animal Production}

\section{System}

The development of a sustainable ruminant animal production system requires careful thoughts and attention to the regional needs and associated preferences. A sustainable system can only be implemented if all relevant components of the society such as farmers, farm workers, consumers, policy makers, economists, scientists, conservationists, environmentalists, educationists and marketing experts contribute to the success of such a system. Therefore, a multi-factorial approach is required when developing a sustainable animal production system to suit various situations in different parts of the world. Figure 2 summarises the main components of this complex approach which could form the basis for the development of a sustainable animal production system to suit different needs and requirements.

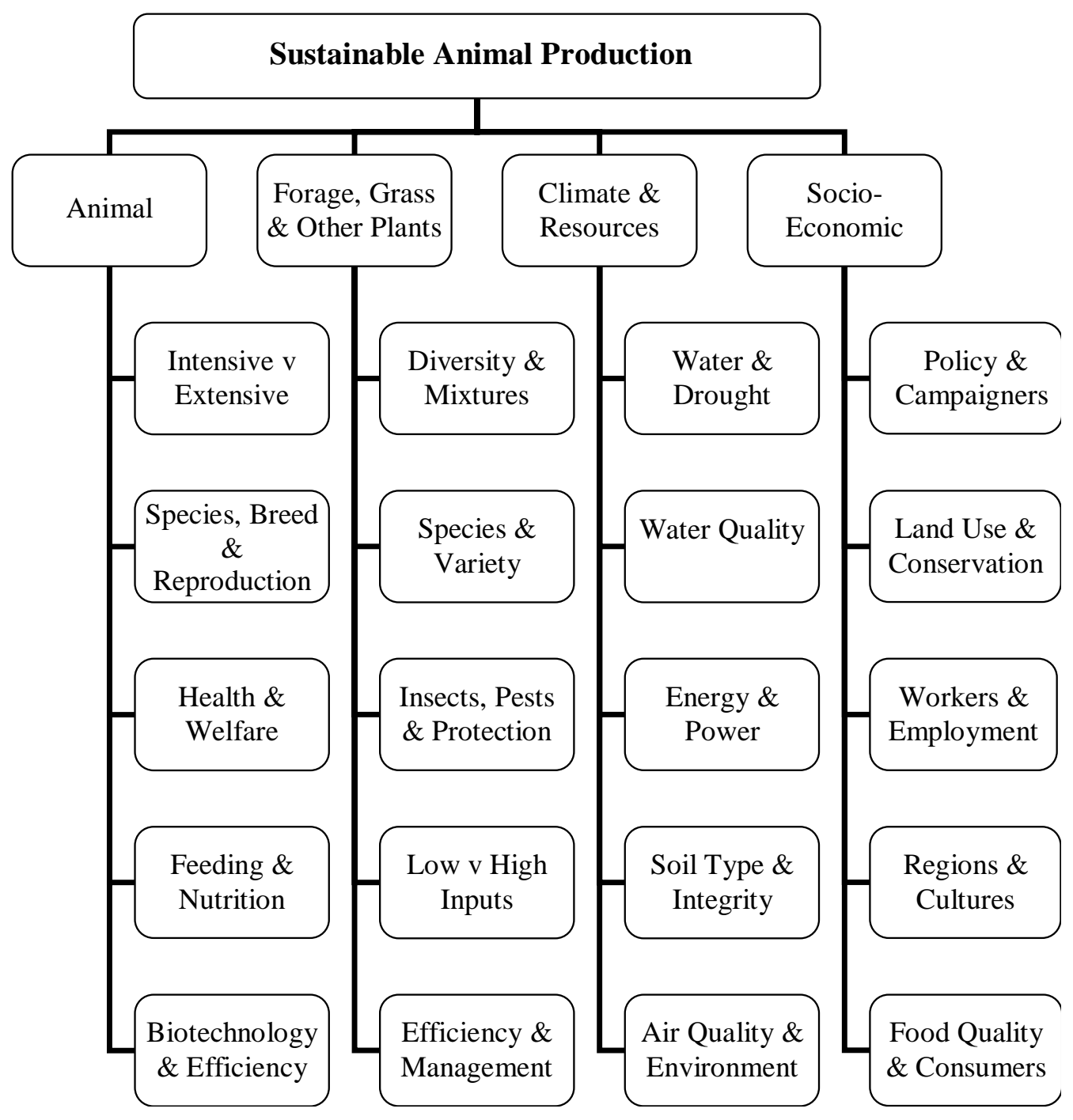

Figure 2. Potential components to achieve Sustainable Animal Production

It is evident from Figure 2 that an integrated approach is needed to develop a sustainable animal production system. Therefore, the following sections briefly describe some of the most important factors that 
may be relevant to the sustainability of a forage based animal production system.

\section{Animals and Forages}

Ruminant animals and forages are two of the most significant factors in any animal production system. The selection of a suitable animal and forage type should be important when implementing the recommendations of the Curry Report (2002) and the Sustainable Farming and Food Research Priorities Group. Also, EU Water Framework Directive and Kyoto protocol expect nations to reduce the impact of livestock production on water and air quality in the form of excretion and gaseous emissions. Yan and Mayne (2007) have reported the variable and sometimes contrasting impacts of fresh $\mathrm{v}$ dry forages, Holstein $\mathrm{v}$ Norwegian cows, and first $\mathrm{v}$ other lactations on the manure $\mathrm{N}$ in various situations. These variable responses could be used for selection when developing or maintaining a sustainable animal production system. Marshall (2007) has shown that new white clover varieties were able to maintain production even at low levels of soil Phosphorus (P) through improved $\mathrm{P}$ utilisation and thus reducing the need to use high levels of P fertilisers. Lotus or Birdsfoot (Lotus corniculatus) was also found to improve protein utilisation by the ruminant animals and reduce methane emission and diffused $\mathrm{N}$ pollution when consumed as a major part of the ruminant diet (Abberton et al., 2006). Moreover, Takahashi et al. (1999) reported variable methane outputs in sheep when consuming dried forms of either Rhodes grass or Lucerne alone. Chaudhry et al. (1998) also observed the benefits of dietary manipulations in modifying the methane output from sheep. This implies that the selection of appropriate forages or feed compositions could be crucial in modifying the impact of feeding on the nutrient wastage from ruminants. Tedstone (1997) supported the benefits of using mixed swards of ryegrass and white clover due to their persistence, palatability, digestibility and availability for extended grazing. Other grasses, legumes and cereals can also be tested for their roles for sustainable animal production. Similar research in new forages could help reduce the effects of animal production on climate change. In fact, these forages could be tested further for their environmental benefits and contribution to the sustainable animal production (Dale et al., 2007). More research on the suitability of animal species and genotypes to utilise available feed resources more effectively may also help in our efforts to develop sustainable forage based animal production.

\section{Better Pastures \& Extended Grazing Season}

Grass based animal production is considered to be the most cost-effective and sustainable system. Therefore, it is essential to develop pastures which are weed free, pest resistant, productive and adaptable to various situations. The role of high value grassland in providing biodiversity, a clean environment and premium quality meat has been emphasised by Wood et al. (1997). Also, it is also crucial to improve forage utilisation and reduce nutrient wastage through appropriate means. One possibility to achieve this is by mixing grass with legumes in pastures to get better production and forage utilisation and hence animal production. DEFRA (2002) reported $41 \%$ more growth and $18 \%$ more grass cover $(\mathrm{kg} / \mathrm{ha})$ for grazing in new leys containing white clover plus ryegrass swards than the other averages of the same farms. By extending the duration of grazing on these pastures in spring by 62 days (started on 9 Feb v 12 April), the farm was able to reduce silage usage but gained more milk and income per dairy cow (Table 2). In addition, the farm was able to reduce other fixed costs involving machinery, labour, purchased feed and bedding etc with a potential for total cost savings of $£ 36000$ for a 100 -cow herd which was equivalent to about 5 pence saving per litre of milk in 2000. However, it is essential to avoid overgrazing which can damage the resources very badly as it has been reported in the tropical SAVANAH area called “CERRADO” (Sainz et al., 2004).

Table 2. The effect of early grazing involving extra days on daily silage intake $(\mathrm{kg})$, milk yield $(\mathrm{L})$ and profit in pence $(p)$ lcow at a pre-selected farm (DEFRA, 2002)

\begin{tabular}{cccc}
\hline Items & $\begin{array}{c}\text { Milk (L) } \\
\text { Production }\end{array}$ & Silage intake & Profit \\
\hline Housed & 18.2 & 13.5 & - \\
\hline After turnout & 19.7 & 10.0 & - \\
\hline Difference & +1.5 & -3.5 & - \\
\hline Gain /day /cow & $+27 p$ & $+29 p$ & $+56 \mathrm{p}$ \\
\hline
\end{tabular}

\section{Supplements}

While animals consuming good quality grass (fresh, dried or ensiled) may not require additional supplements during non productive situations, they do 
need supplementation when consuming mature forages or crop residues such as cereal straws. Therefore the selection of an appropriate supplement to enhance forage utilisation to reduce nutrient wastage and sustain animal growth and production will be crucial. Bargo et al., (2003) have reviewed the benefits of supplementing dairy cows in terms of improved pasture utilisation and enhanced dairy production during grazing on pastures. As grass is low in some minerals, the animal production and health could be affected if grass is fed without supplements. Thus, it is essential to find complementary energy and mineral sources to boost grass digestibility and intake to sustain animal health and performance. This could be achieved by using molasses or chelated minerals to compensate for the nutrient deficits in forages including grass and straw (Underwood \& Suttle, 2001). Chaudhry (2008) has reported variable forage degradability in vitro when two different combinations of molasses and chelated minerals were tested at various levels in a rumen simulated system. This shows the importance of matching a supplement with appropriate forages to get maximum benefits of supplementing forage consuming animals. Also, substantial increases in the forage intake and growth of Holstein-Friesian heifers were observed when these heifers were offered nutrient rich feed blocks on self help basis during grazing on mature ryegrass swards (Chaudhry et al., 2005). The benefits of similar feed blocks on the breeding performance of breeding ewes while consuming grazed ryegrass have also been observed (Chaudhry, 2006). Although expansion in the bio-fuel industry is creating concerns about food security, its by-products offer opportunity for their use as supplements for forage based animal production systems.

\section{Importance of Crop Residues and Biofuels}

The increased use of cereals such as maize and wheat and legumes such as oil seed rape to produce biofuels could have an impact on their availability as dietary constituents or supplements for animal production. It is therefore important to increase focus on alternative forages for animal production. Crop residues such as cereal straws and stovers and tree leaves could be beneficial in the supply of nutrients in a forage based animal production especially when grass and other forages are in short supplies. Their utilisation can be improved by using either chemical or biological pretreatments (Chaudhry, 1998) or physical processing (Rezaeian et al., 2006) or spices as novel supplements (Khan \& Chaudhry, 2008). However, the recent interest in using cellulose rich plants to produce bio-fuels may affect the availability of these crop residues as a useful nutrient source for ruminant animals. In return the residues from the biofuel industry could become new sources of nutrients to meet the demands of a sustainable animal production.

\section{Technology \\ Improved Animal Breeding and Gene}

Improved animal breeding for disease resistance, forage utilisation, food quality and the environment is considered beneficial for the sustainability of animal production systems (SABRE, 2006). It is estimated that animal diseases cost about 17 and $35 \%$ of total production costs in the developed and developing countries respectively. The need to produce disease resistant animals becomes even more important with the European ban on the use of antibiotics for growth and farm animal production. Therefore, the selection of an appropriate animal species (e.g. buffalo v cattle) or a breed with improved disease resistance or other desirable traits to match the available forage type and amount would be important in the sustainability of a forage based animal production system. The requirements of different developing and developed counties will have to be considered in selecting an existing animal species or breed or improving the traits of these animals for the sustainability of animal production systems. The availability and improved understanding of modern gene based technologies should help us identify and develop the most desirable traits in animals. These improved traits should prepare the animals for adaptation to the changing scenarios of animal production for the current and future generations.

\section{Climate Change and Socio-Economic Issues}

The effect of climate change on seasons in terms of unpredicted droughts and floods in different regions of the world is a matter of concern for people and policy makers alike. While farm animals have been partly blamed for climate change, the potential effects of climate change on food supply for animals and relevant people are also expected. Consequently policies concerning climate change are evolving and these will continue to gain momentum in coming years. Of course, these policies will have an impact on farm animal 
industry and so there is an urgent need to adapt animal production systems to climate change depending upon the needs of different countries. For this purpose, selection and propagation of appropriate plants and animals to suit different tropical and temperate regions would be needed to sustain desirable production. Such an approach will affect the cost structures of animal industry and ultimately the social and economical aspects of all relevant people from the farm workers to the consumers. Therefore, careful thought and planning will be needed when developing forage based animal production systems to mitigate the detrimental effects of climate change on animals and without affecting the supply and quality of water and food for human consumption.

\section{Conclusions}

The sustainability of forage based animal production systems is vital to supply quality, safe and affordable food for the ever growing human population. It is therefore essential that these systems are adaptable to the current issues of climate change and the needs of rural populations who are associated with animal production in both developed and developing countries. For this purpose an interdisciplinary approach by involving consumers, farmers, environmentalists, animal scientists, sociologists, economists, and policy makers is required to achieve the real objectives and benefits of a sustainable animal production system. However, the sensible use of supplements and herbal additives as the desirable alternatives to the conventional growth promoters may be the key in optimising the forage utilisation and reducing the nutrient wastage from animal production systems.

\section{Acknowledgments}

I thank the Brazilian Society of Animal Science for their financial support to present this invited paper at their $45^{\text {th }}$ annual meeting

\section{References}

ABBERTON, M.T.; FORTHERGILL, M.; COLLINS, R.P.; MARSHALL, A.H. Breeding forage legumes for sustainable and profitable farming systems. Aspects of Applied Biology, v.80, p.81-87, 2006.
BARGO, F.; MULLAR, L.D.; KOLVER, E.S.; DELAHOY, J.E. Invited review: Production and digestion of supplemented dairy cows on pasture. Journal of Dairy Science, v.86, p.142, 2003.

CHAUDHRY, A.S.; LISTER, C.J.; TAYLOR, W. Effect of feed blocks on the growth of grazing heifers. In (ed): Strandberg, E., Cenkvari, E., Von Borell, E., Kemp, B., Lazzaroni, C., Gauly, M., Wenk, C., Martin-Rosset, W., Bernues Jal, A. and Thomas, C. Proceedings of 56th Annual meeting of the EAAP in Uppsala, 5-8 June, Abstract 15.17, p. 141, 2005.

CHAUDHRY, A.S.; TAKAHASHI J.; YOUNG, B.A. Dietary modification of methane emission in sheep. Animal Production in Australia, v. 22, p. 381, 1998.

CHAUDHRY, A.S. Chemical and biological procedures to upgrade cereal straws for ruminants. Nutrition Abstracts and Reviews, series B, v.5, p. 319-331, 1998.

CHAUDHRY, A.S.; Suppplementary feeding of breeding ewes consuming grass based diets. In (ed) Strandberg, E., Moreira, O., Fourichon, C., Vestergaard, M., Lazzaroni, C., Gauly, M., Wenk, C., Martin-Rosset, W., Hermansen, J. and Thomas, C. Proceedings of 57th Annual meeting of the EAAP at Antalya, Turkey, 17-20 September, Abstract N18.11, 2006.

CHAUDHRY, A.S.; Slaughtered Cattle as a Source of Rumen Fluid to Evaluate Supplements for In vitro Degradation of Grass Nuts and Barley Straw. The Open Veterinary Science Journal, v.2, 16-22, 2008.

DEFRA. Demonstration of progressive farming practice for grassland / livestock enterprises. A Final Project Report (LS1603), 2002. (http://www2.defra.gov.uk/research/Project_Data/projects.as $\mathrm{p}$ ? $\mathrm{M}=\mathrm{CFO} \& \mathrm{~V}=\mathrm{GLAS}$ ).

CURRY, D. Farming and Food: A sustainable future. 2002. http://archive.cabinetoffice.gov.uk/farming/pdf/PC\%20Repo rt2.pdf

DALE, LAIDLAW,A.S.FROST,J.P.;BAILEY,J.;MAYNE,C.S.;

Opportunities to improving efficiency of use of animal manures with low input, alternative forages. In: HOPKIN, J.; DUNCAN, A.J.; McCRACKEN, D.I.; PEEL, S.; TALLOWIN, J.R.B. (Ed.) High value grassland: Providing biodiversity, a clean environment and premium products. Occasional symposium, British Grassland Society, v38. p. 205-208, 2007

FAO. The strategic framework for FAO 2000-2015. http://www.fao.org. 2000.

HALL, M.; DIXON, J.; GULLIVER, A.; GIBBON, D. Farming systems and Poverty: Improving farmers' livelihoods in a changing World. FAO and World Bank, Rome, 2001.

KHAN, M.M.H.; CHAUDHRY, A.S. Effect of spice supplementation on rumen ammonia concentration in vitro. Proceedings of the British Society of Animal Science, p.36, 2008.

MARSHALL, A.H. Developing selection criteria for forage legumes that balance production, biodiversity and reduced environmental pollution.Final Report LS3643, 2007.(http://www.defra.gov.uk/science/project_data/Docum entLibrary/LS3643/LS3643_5780_FRP.doc)

OLTJAN, J. W.; BECKETT, J.L. Role of ruminant livestock in sustainable agricultural systems. Journal of Animal Science, v. 74, p. 1406-1409, 1996.

REZAEIAN, M.; BEAKES, G.W.; CHAUDHRY, A.S. Effect of feeding chopped and pelleted Lucerne on rumen fungal 
mass, fermentation profiles and in sacco degradation of barley straw in sheep. Animal Feed Science and Technology, v. 128, p. 292-306, 2006.

SABRE. Cutting Edge Genomics for Sustainable Animal Breeding, A European funded project. (http://www.sabreeu.eu/), 2006.

SAINZ, R.D.;MAGNABOSCO, C.U.; BARBOSA, V.; BARCELLOS, A.O.; VILELA, L., DE FARIA, C.U.; BALBINO, L.C. Performance of Nellore cattle on renovated pastures of the Brazilian Cerrado (tropical savannah). In: Responding to Livestock revolution in Marida, Mexico, 2002. BSAS Occasional Publication, 33:183-184, 2004.

TAKAHASHI, J.; CHAUDHRY, A.S.; BENEKE, R.G.; YOUNG, B.A.; An open circuit hood system for gaseous exchange measurements in small ruminants. Small Ruminant Research, v. 32, p.31-36, 1999.

TEDSTONE, G.E.C. Low input systems. In :WEDDLE, J.R (ed). Seed of Progress. Occasional Symposium, British Grassland Society, 31, p.41-45, 1997.

UNDERWOOD, E.J.; SUTTLE, N.F. The Mineral Nutrition of Livestock. CAB International, Wallingford, Oxon. 2001.
UNITED NATIONS. Report of the World Commission on Environment and Development. General Assembly Resolution 42/187, 11 December. 1987. Retrieved: December, 2007.

VAVRA, M.; Sustainability of Animal Production Systems: An ecological Perspective. Journal of Animal Science, v. 74, p.1418-1423, 1996.

WOOD, J.D.; RICHARDSON, R.I.;SCOLLON, N.D.; HOPKIN, A.; DUNN,R.; BUTLER,H.;WITTINGTON,F.M. Quality of meat from biodiverse grassland. In: HOPKIN, J.; DUNCAN, A.J.; McCRACKEN, D.I.; PEEL, S.; TALLOWIN, J.R.B. (Ed.) High value grassland: Providing biodiversity, a clean environment and premium products. Occasional symposium, British Grassland Society, v. 38, p. 107-116, 2007.

YAN, A.; MAYNE, C. Management and nutritional approaches to reduce manure nitrogen excretion of lactating dairy cows. In: HOPKIN, J.; DUNCAN, A.J.; McCRACKEN, D.I.; PEEL, S.; TALLOWIN, J.R.B. (Ed.)High value grassland: Providing biodiversity, a clean environment and premium products. Occasional symposium, British Grassland Society, v38. p. 70-75, 2007. 